\title{
APLIKASI PEMBELAJARAN TEKNIK DASAR SEPAK BOLA BERBASIS ANDROID
}

\author{
Rais Firlando ${ }^{1}$, Aren Frima ${ }^{2}$, Lukman Sunardi ${ }^{3}$ \\ ${ }^{1}$ Program Studi Pendidikan Jasmani, Kesehatan, dan Rekreasi STKIP PGRI Lubuklinggau \\ ${ }^{2}$ Program Studi Pendidikan Sekolah Dasar STKIP PGRI Lubuklinggau \\ ${ }^{3}$ Program Studi Informatika Universitas Bina Insan Lubuklinggau \\ e-mail: 'raisfirlando@ stkippgri-lubuklinggau.ac.id, ${ }^{2}$ frimasoemantri@ gmail.com, \\ 3lukmansunardi@univbinainsan.ac.id
}

\begin{abstract}
Abstrak
Dalam dunia pendidikan dan pengajaran, untuk menarik minat dan menambah pengetahuan serta pehamahaman siswanya, tentunya harus memiliki inovasi dan kreatifitas untuk meningkatkan prestasi belajar siswanya terutama dalam pembelajaran teknik dasar sepak bola. Untuk menjawab tantangan tersebut, peneliti akan membuat suatu model media pembelajaran berbasis android untuk pembelajaran teknik dasar sepak bola di SMP Ar Risalah Lubuklinggau. Pemilihan media pembelajaran berbasis android ini dikarenakan siswa dan guru sudah familiar dengan penggunaan mobile gadget berbasis android. Dalam perancangannya, peneliti melakukan pendekatan metode pengembangan sistem prototype.Tahapan perancangan awal dimulai dengan analisis kebutuhan data, kemudian dilanjutkan dengan membangun desain prototype sistem dengan menggunakan Unified Modelling Language (UML). Untuk perancangan prototype sistem menggunakan bahasa pemrograman Java dengan IDE Android Studio. Hasil akhir dari sistem ini adalah purwarupa (Prototype) aplikasi media pembelajaran teknik dasar sepakbola berbasis android.
\end{abstract}

Kata kunci : Pembelajaran Sepak Bola; Aplikasi; Android

\begin{abstract}
In the world of education and teaching, to attract interest and increase the knowledge and understanding of students, of course, one must have innovation and creativity to improve student learning achievement, especially in learning basic soccer techniques. To answer this challenge, the researcher will create an Android-based learning media model for learning basic soccer techniques at SMP Ar Risalah Lubuklinggau. The choice of learning media based on android is because students and teachers are familiar with the use of android-based mobile gadgets. In the design, researchers approached the prototype system development method. The initial design stages began with an analysis of data requirements, then continued with building a system prototype design using Unified Modeling Language (UML). To design a system prototype using the Java programming language with IDE Android Studio. The end of this system is a prototype application of learning media for basic techniques of football based on Android.
\end{abstract}

Keywords : Football Learning; Application; Android 
I

\section{PENDAHULUAN}

Sepakbola adalah salah satu cabang olahraga yang paling banyak digemari dan menarik perhatian masyarakat saat ini tak terkecuali dikota lubuklinggau khususnya. Banyaknya informasi tentang sepakbola yang disajikan oleh berbagai media adalah salah satu indikasi paling nyata dari pernyataan bahwa sepakbola adalah olahraga paling hits atau popular di kalangan masyarakat baik orang dewasa, remaja bahkan anak-anak sekalipun. Rekaman dan ulasan jalannya pertandingan dilapangan, profil pemain dan pelatih hingga stadion tempat berlangsungnya pertandingan merupakan cerita menarik yang dibahas pada media elektronik maupun media cetak. Di Indonesia minat anak terhadap permainan sepakbola juga sangat tinggi. Khususnya di Kota Lubuklinggau sangat banyak pembinaan sepakbola yang dilakukan oleh pihak lembaga maupun swasta. Pembinaan siswa usia dini ini tentu sangat bagus untuk perkembangan sepakbola di Indonesia. Karena dengan adanya pembinaan ini dapat mempersiapkan pemain dari usia dini. Tetapi pemahaman anak tentang materi teknik dasar dalam bermain sepakbola masih sangat kurang. Anak hanya mengandalkan jam pelajaran olahraga disekolah untuk menambah keterampilannya. Kurangnya pengetahuan dan pemahaman siswa terhadap materi membuat siswa tergantung pada guru yang ada di sekolah. Minimnya sumber pembelajaran atau media pembelajaran menyulitkan siswa dalam mengembangkan bakat mereka secara mandiri.

Pengembangan aplikasi berbasis android telah banyak dikembangkan sebagai media pembelajaran, antara lain: pengembangan aplikasi berbasis android untuk materi penjas-pedia di SMPN 1 Bangkalan [1], pembuatan aplikasi media pembelajaran pendidikan jasmani dan olahraga berbasis android di SMAN 5 Palopo [2], dan aplikasi media pembelajaran olahraga bola basket menggunakan adobe flash [3].

Permasalahan yang akan dibahas dalam penelitian ini mengenai bagaimana mengembangkan aplikasi media pembelajaran teknik dasar olahraga sepakbola berbasis android untuk meningkatkan hasil pengetahuan siswa, membangkitkan minat dan keinginan siswa tentang sepakbola.

\section{TINJAUAN PUSTAKA}

\subsection{Teknik Dasar Sepakbola}

Kemampuan dasar keterampilan sepakbola meliputi: a). Menendang bola (kicking/passing), b). Menghentikan bola (stoping), c). Menggiring bola (dribbling), d). Menyundul bola (heading), e). Merampas bola (tackling), f). Lemparan ke dalam (throw-in), g). Menjaga gawang (goal keeping) [4]. Tujuh kemampuan dasar keterampilan sepakbola dapat dijelaskan sebagai berikut:

\section{$1 \quad$ Menendang}

Menendang bola merupakan salah satu karakteristik permainan sepakbola yang paling dominan. Pemain yang memiliki teknik menendang dengan baik, akan dapat bermain secara efisien. Tujuan menendang bola adalah untuk mengumpan (passing), menembak ke gawang (shooting at the goal), dan menyapu untuk menggagalkan serangan lawan (sweeping). Dilihat dari perkenaan bagian kaki ke bola, menendang dibedakan menjadi beberapa macam, yaitu menendang dengan kaki bagian dalam (inside), kaki bagian luar (outside), punggung kaki (instep) dan punggung kaki bagian dalam (inside of the instep) [4].

\section{Menghentikan Bola}

Menghentikan bola merupakan salah satu teknik dasar dalam permainan sepakbola yang penggunaannya bersamaan dengan teknik menendang bola. Tujuannya menghentikan bola untuk mengontrol bola 
[4]. Dilihat dari perkenaan bagian badan yang pada umumnya digunakan untuk menghentikan bola adalah kaki, paha, dan dada. Bagian kaki yang biasa digunakan untuk menghentikan bola adalah kaki bagian dalam, kaki bagian luar, punggung kaki, dan telapak kaki.

\section{Menyundul Bola}

Menyudul bola adalah meneruskan bola dengan mempergunakan dahi yaitu daerah kepala di atas kening di bawah rambut [5]. Dengan kata lain menyundul adalah memainkan bola dengan kepala.

\section{Menggiring Bola}

Pada dasarnya menggiring bola adalah menendang terputus-putus atau pelan-pelan, menggiring bola bertujuan antara lain untuk mendekati jarak ke sasaran, melewati lawan, dan menghambat permainan [4]. Pemain dapat terkenal oleh karena memiliki kemampuan menggiring bola yang baik.

5 Merampas/merebut Bola

Merampas bola adalah salah satu upaya untuk merebut bola dari penguasaan lawan [4].

\section{Lemparan ke Dalam (throw in)}

Lemparan ke dalam merupakan satusatunya teknik dalam permainan sepakbola yang dimainkan dengan lengan dari luar lapangan permainan [4].

\section{Gerak tipu dengan bola (feinting)}

Gerak tipu dilakukan oleh seorang yang menguasai bola dengan tujuan untuk melewati lawan, sehingga mampu melakukan operan bola ke teman dengan baik ataupun mencetak gol ke gawang lawan. Perlu diperhatikan bahwa di dalam melakukan gerak tipu, gerakan permulaan bertujuan untuk mengganggu atau menghilangkan keseimbangan lawan, tidak boleh dilakukan dengan sepenuhnya sehingga kehilangan keseimbangan badan sendiri [5].
8 Menjaga Gawang

Menjaga gawang merupakan pertahanan yang paling akhir dalam permainan sepakbola [4]. Teknik menjaga gawang meliputi: menangkap bola, melempar bola, menendang bola. Menangkap bola dapat dibedakan berdasarkan arah datangnya bola, ada yang datangnya bola masih dalam jangkauan penjaga gawang (tidak meloncat) dan ada yang diluar jangkauan penjaga gawang (harus dengan meloncat). Melempar bola dapat dibedakan berdasarkan jauh dekatnya sasaran.

\subsection{Media Pembelajaran}

Kata media berasal dari bahasa latinyaitu media yang secara harfiah berarti "tengah, perantara, atau pengantar" [6]. Sedang AECT (Association of Education and Communication Technology) memberi batasan mengenai media sebagai segala bentuk dan saluran yang digunakan untuk menyampaikan informasi [7]. Secara lebih khusus, pengertianmedia dalam proses belajar mengajar cenderung diartikan sebagai alat-alatgrafis, photografis, atau elektronis untuk menangkap, memproses, dan menyusun kembali informasi visual atau verbal. Sehingga dapat diartikansebagai alat yang menyampaikan atau mengantarkan pesan-pesan pembelajaran.

\subsection{Android}

Android merupakan subset perangkat lunak untuk perangkat mobile yang meliputi sistem operasi, middleware dan aplikasi inti yang di-release oleh Google [8]. Sedangkan Android SDK (Software Development Kit) menyediakan Tools dan API yang diperlukan untuk mengembangkan aplikasi pada platform Android dengan menggunakan bahasa pemrograman Java. 


\section{METODOLOGI PENELITIAN}

Penelitian ini menggunakan metode pengembangan sistem dengan metode Prototype. Prototype adalah model atau simulasi dari semua aspek produk sesungguhnya yang dikembangkan yang dimana model tersebut harus representatif dari produk akhirnya.

1. Komunikasi

Pelanggan dan pengembang bersamasama mendefinisikan format dan kebutuhan keseluruhan perangkat lunak, mengidentifikasikan semua kebutuhan, dan garis besar sistem yang dibuat.

Dalam tahapan ini, peneliti menganalisis kebutuhan yang digunakan untuk terwujudnya pengembangan aplikasi media pembelajaran teknik dasar sepakbola berbasis android. Analisis yang didapat antara lain: 1) Dapat menampilkan teori dasar, 2) Dapat menampilkan praktek berupa gambar, 3) Dapat menampilkan tes soal teknik dasar.

\section{Desain Sistem}

Pada tahap ini peneliti membuat desain dari sistem yang dibuat berupa struktur data, arsitektur perangkat lunak menggunakan diagram bantu Use Case Diagram, dan representasi antarmuka yang diimplementasikan menjadi program pada tahap selanjutnya. Gambar 1 menampilkan use case dari sistem yang dibangun.

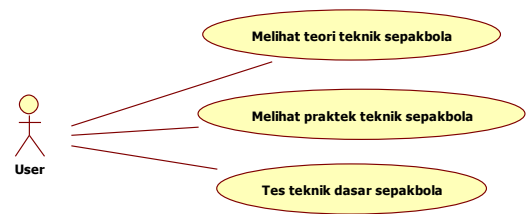

Gambar 1. Use Case Diagram

3. Pembuatan Kode Program

Pada proses ini, peneliti melakukan kegiatan pembuatan kode program (coding). Hasil dari tahap ini adalah aplikasi media pembelajaran teknik dasar sepakbola berbasis android.
4. Pengujian

Metode pengujian software adalah cara atau teknik untuk menguji perangkat lunak, mempunyai mekanisme untuk menentukan data uji yang dapat menguji perangkat lunak secara lengkap dan mempunyai kemungkinan tinggi untuk menemukan kesalahan Perangkat lunak dapat diuji.

\section{HASIL DAN PEMBAHASAN}

Aplikasi pembelajaran teknik dasar sepakbola berbasis android ini menyajikan media pembelajaran yang dapat dikases melalui gawai android. Berikut tampilan dari aplikasi pembelajaran ini.

\section{Halaman Utama}

Halaman utama menampilkan menumenu yang ada di aplikasi meliputi teknikteknik dasar dalam sepakbola. Gambar 2 menampilkan halaman utama aplikasi.

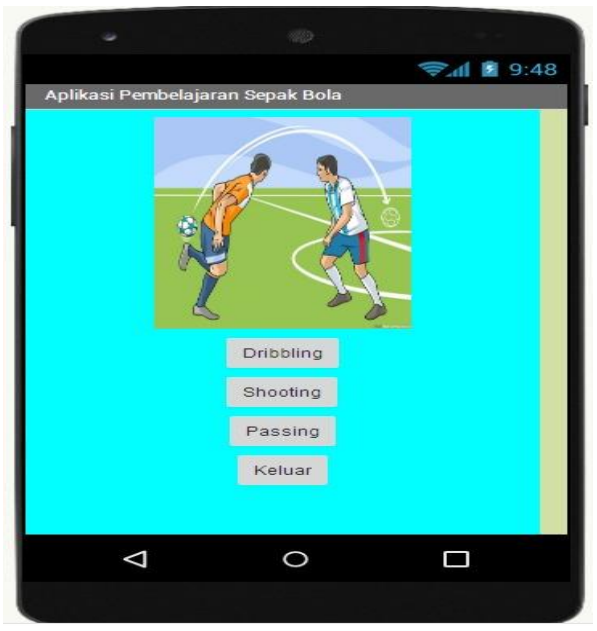

Gambar 2. Tampilan Halaman Utama

2. Halaman Dribbling

Halaman dribbling menampilkan gambar-gambar teknik mendribbling bola. Gambar 3 menampilkan Halaman dribbling. 


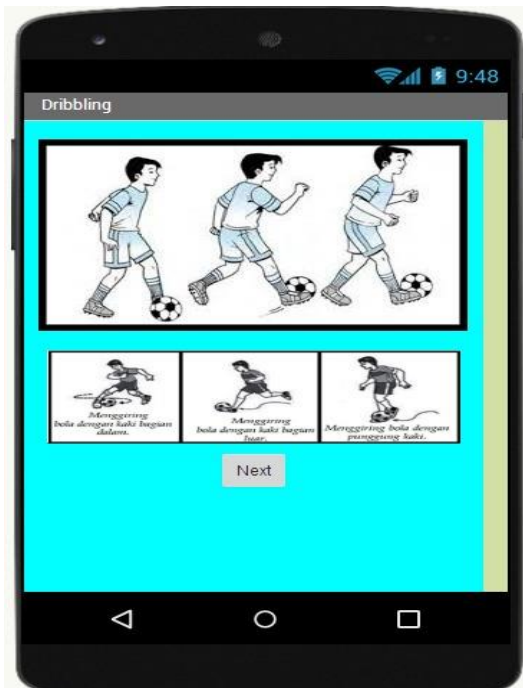

Gambar 3. Tampilan Halaman Dribbling

3. Halaman Keterangan Dribbling

Halaman Keterangan dribbling menampilkan informasi tentang teknikteknik mendribbling bola. Gambar 4 menampilkan Halaman keterangan dribbling.

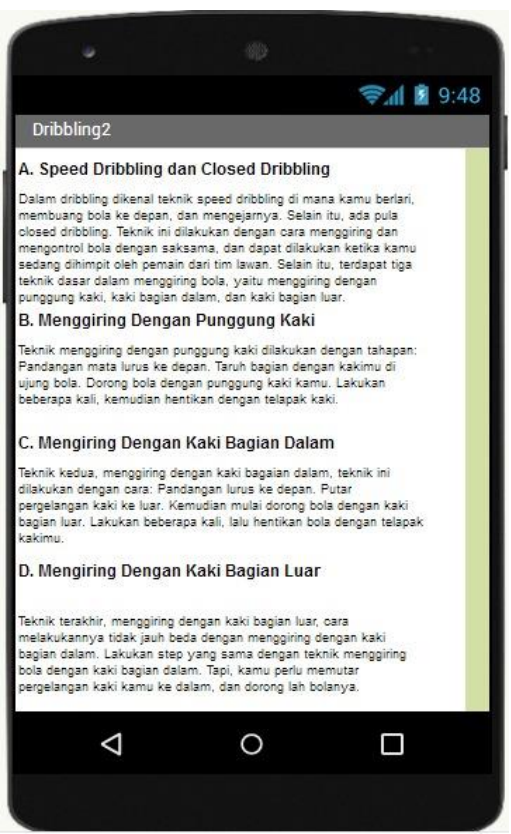

Gambar 4. Tampilan Halaman Keterangan Dribbling

\section{Halaman Shooting}

Halaman Shooting menampilkan gambar-gambar teknik melakukan shooting bola. Gambar 5 menampilkan Halaman shooting bola.

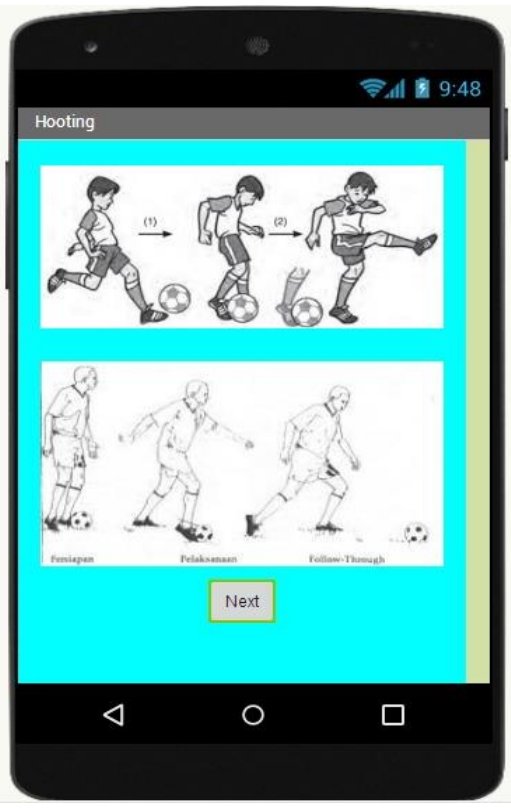

Gambar 5. Halaman Shooting

5. Halaman Keterangan Shooting

Halaman Keterangan shooting menampilkan informasi tentang teknikteknik shooting bola. Gambar 6 menampilkan Halaman keterangan shooting.

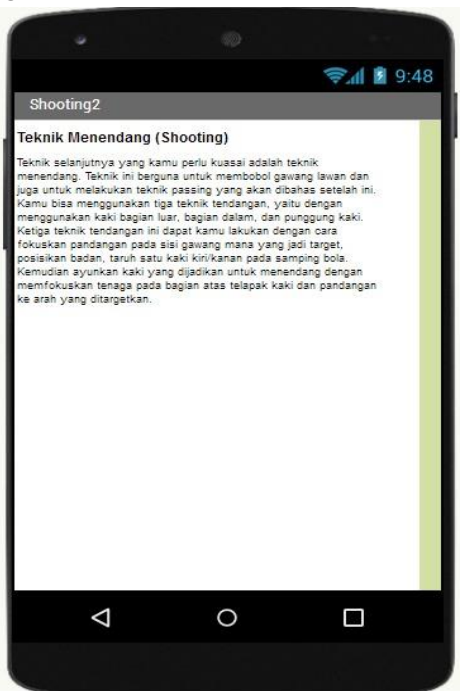

Gambar 6. Halaman Keterangan Shooting 
6. Halaman Passing

Halaman passing menampilkan gambar-gambar teknik melakukan passing bola. Gambar 7 menampilkan Halaman passing bola.

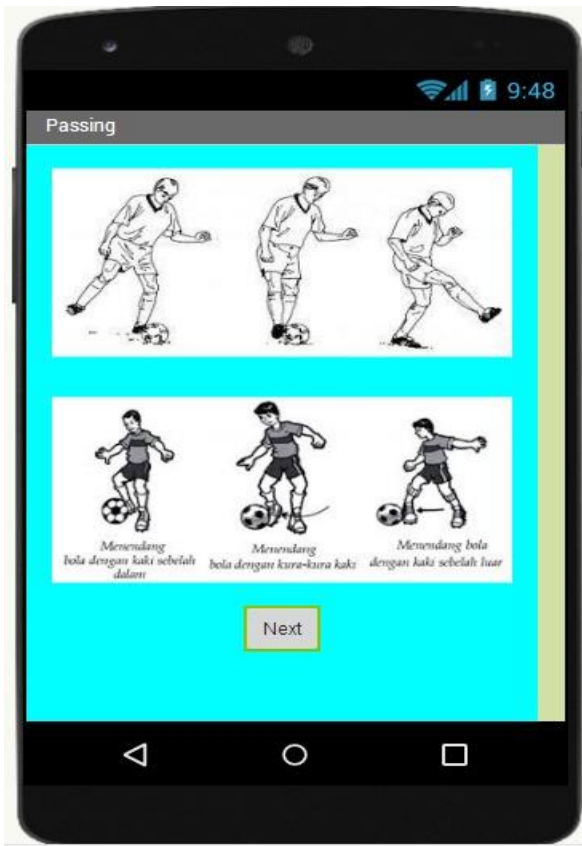

Gambar 7. Tampilan Halaman Passing Bola

7. Halaman Keterangan Passing

Halaman Keterangan passing menampilkan informasi tentang teknikteknik passing bola. Gambar 8 menampilkan Halaman keterangan passing.

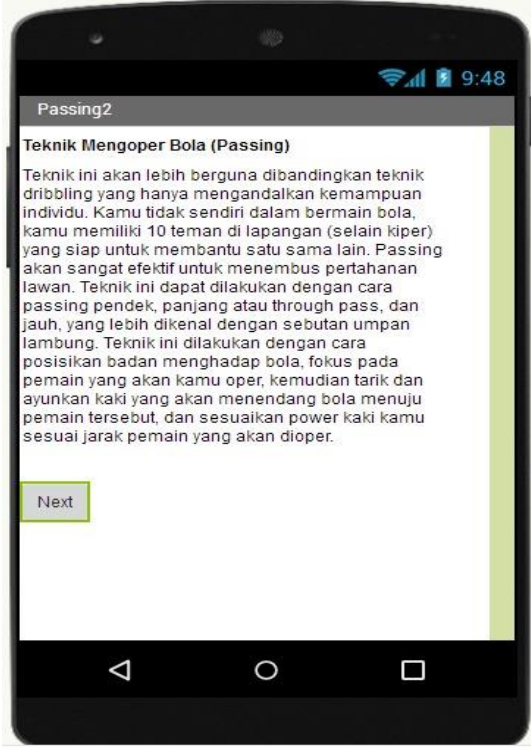

Gambar 8. Halaman Keterangan Passing
8. Halaman Keterangan Menghentikan Bola

Halaman Keterangan menghentikan bola menampilkan informasi tentang teknik-teknik menghentikan bola. Gambar 9 menampilkan Halaman keterangan menghentikan bola.

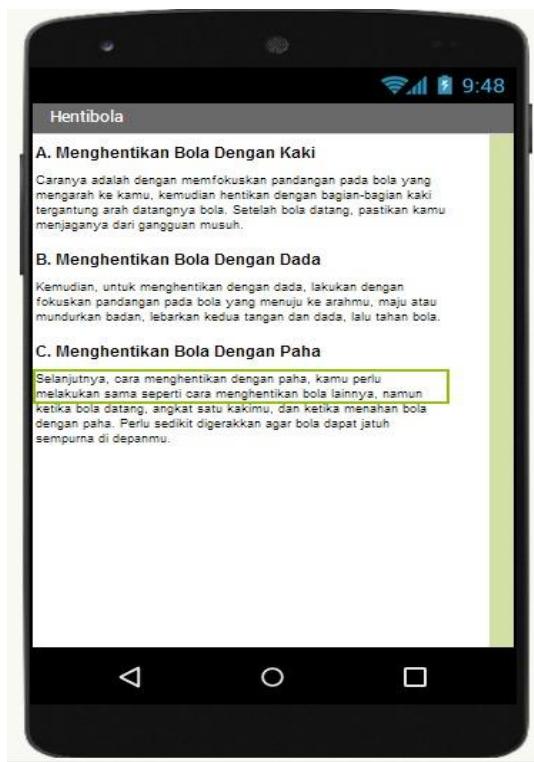

Gambar 9. Halaman Keterangan Menghentikan Bola

\section{KESIMPULAN}

Dari pembahasan diatas, dapat disimpulkan bahwa media pembelajaran teknik dasar sepakbola dapat diterapkan dengan baik berbasis android. System dapat diakses melalui perangkat yang menggunakan sistem operasi android mana saja dan kapan saja sehingga pengguna dapat mengakses media pembelajaran tersebut secara portable.

\section{SARAN}

Kepada semua pihak yang berniat untuk mengadakan penelitian dengan tema serupa, disarankan untuk memberikan tambahan antara lain: media gambar yang lebih interaktif dengan menggunakan multicolor image. 
VII DAFTAR PUSTAKA

[1] H. Marvin, "Pengembangan Aplikasi PENJAS- PEDIA Pada Smartphone Berbasis Android Sebagai Media Pembelajaran Pendidikan Jasmani Untuk Kelas VII di SMP N 1 Bangkalan," vol. 1, no. November, pp. 28-33, 2018.

[2] J. Jusrianto, A. Zahir, and A. Muthmainnah, "Pembuatan Aplikasi Media Pembelajaran Pendidikan Jasmani Dan Olahraga Berbasis Android pada SMA Negeri 5 Palopo," vol. 2014, pp. 73-83, 2019.

[3] Khairunnisa, "Aplikasi Media Pembelajaran Olahraga Bola Basket Menggunakan Adobe Flash," Query J. Sist. Inf., vol. 3, no. 1, pp. 78-85, 2019.

[4] Sucipto and Dkk, Sepakbola. Jakarta: Depdikbud Dikti, 2000.

[5] Sukatamsi, Teknik Dasar Bermain Sepakbola. Solo: Tiga Serangkai, 2001.

[6] A. Arsyad, Media Pembelajaran, 16th ed. Jakarta: Raja Grafindo Persada, 2013.

[7] Usman, Media Pembelajaran, 1st ed. Jakarta: Ciputat Press, 2002.

[8] S. N, Android Pemograman Aplikasi Mobile Smartphone Dan Tablet PC Berbasis Android. Bandung: Penerbit Informatika, 2011. 